International Journal of Instruction e-ISSN: 1308-1470 • www.e-iji.net

Article submission code: 20191231110118

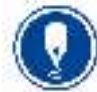

January $2021 \bullet$ Vol.14, No.1

p-ISSN: 1694-609X

рр. $489-506$

Received: 31/12/2019

Revision: 05/07/2020
Accepted: 27/07/2020

OnlineFirst: 25/10/2020

\title{
A Review of Kosovo's 2015 PISA Results: Analysing the Impact of Teacher Characteristics in Student Achievement
}

\author{
Albulene Grajcevci \\ PDI-Professional Development Institute Prishtina, Kosovo, grajcevci.albulene@pdi- \\ ks.org
}

Arif Shala

PDI-Professional Development Institute Prishtina, Kosovo, shala.arif@pdi-ks.org

In light of existing research evidence student achievement is considered to be determined to a great extent by the characteristics of teachers. With this in mind, teacher characteristics have become an important variable not only in understanding PISA scores but also in drafting new education policies. By analysing PISA results and the data from additional inventories, this paper argues that the data on teacher characteristics is inconclusive and in contrast to what literature suggests; practices and techniques that enhance student achievement in other countries are the ones that result in decreased student performance in Kosovo. Importantly, PISA was the only beginning and its findings demand additional research in order to understand how teachers are practicing, what techniques they are using and what the level of their content knowledge is. Once a better understanding of trends and developments in education institutions is gained, government structures can consider a number of practices that have yielded results for other countries. In conclusion, in light of existing results, drafting new policies without conducting extensive research on teacher characteristics in Kosovo is likely to result in failure.

Keywords: teacher characteristics, PISA 2015, student achievement, teacher quality, Kosovo

\section{INTRODUCTION}

"We need to attract the best and brightest to join the profession. Teachers are the key in today's knowledge economy, where a good education is an essential foundation for every child's future success."

(Andreas Schleicher, OECD Director for Education and Skills; National Academies, 2007).

There is a body of research arguing that teachers who provide quality instruction are the ones that influence student performance by increasing it. To that end findings have urged scholars to argue that the most valuable "thing" that the school can give its students is quality teachers (OECD, 2005). This fact coupled with the understanding that

Citation: Grajcevci, A., \& Shala, A. (2021). A Review of Kosovo's 2015 PISA Results: Analysing the Impact of Teacher Characteristics in Student Achievement. International Journal of Instruction, 14(1), 489-506. https://doi.org/10.29333/iji.2021.14129a 
the environment and student populations are changing, has led experts to argue that governments need to do one thing: provide trained teaching staff that keeps up to date with current developments (European Commission, 2004). In light of these findings, teacher quality has been a topic on its own, but it has also been considered in relation to student performance in PISA assessments. Notably, it is generally hypothesized that teacher characteristics are important variables predicting student performance and achievement in PISA tests.

PISA is probably the most interesting "event" of the past 17 years. The organization for Economic Cooperation and Development (OECD) began the first Program for International Student Assessment (PISA) test in 2000 and so its endeavour to test the quality of national education systems began. The organization assessed the quality of education systems by testing 15-year olds on their ability to apply knowledge to the realworld problems. As time passed, PISA became the key source of information necessary to initiate policy changes across education systems (OECD, 2009a; Carvalho, 2012).

Notwithstanding the fact PISA results have generated incredible debates across researchers and experts many of whom have not been supportive of this assessment initiative, PISA tests are an important form of feedback to national education systems. Many argue that PISA has resulted in education systems which focus on economic growth as opposed to promoting reflective and involved citizens (Lawn, 2011; Carvalho, 2012; Mangez \& Hilgers, 2012). Scholars that support PISA argue that this shift is a positive one as it demands that educations institutions develop skills that are need in the new world economy (Schleicher, 2013).Regardless to numerous drawbacks, PISA remains highest authority (Pereyra et al, 2011) that has influenced education changes pertaining to internationalizing and globalizing education(Ozga and Lingard 2007).With this in mind, PISA has successfully attracted attention to the "Knowledge economy" and the concept of lifelong learning.

By contrast, PISA does not serve the purpose of a barometer instead it complements its achievement tests with a number of instruments assessing variables that determine and predict academic performance. To that end this assessment provides governments and policy builders with information about where their education systems are failing. In view of the evidence which places teacher characteristics at the core of student achievement, OECD instruments place considerable emphasis on measuring a number of variables that are generally considered to compose the umbrella term "teacher characteristics".

In the last years, researchers have been intrigued by the link between teacher quality and student achievement and performance (Cordero \& Gil, 2018). Previous research on the influence of teacher quality on student performance noted that indicators such as teacher education, subject knowledge, teaching style and behavior, and cognitive abilities influence student achievement (Meroni, Vera-Toscano \& Costa, 2015). One of the leading scholars in education, Eric Hanushek (2011) argued that schools can do the most important thing for their students and that is offering them good teachers. The research study of Meroni and colleagues, as expected, confirmed the impact of teacher skills and student performance since the quality of teachers explained $14.2 \%$ of the variance in math achievement and $17.1 \%$ in reading achievement in students across OECD 
countries (Meroni, Vera-Toscano \& Costa, 2015). To that end, governments should place emphasis on keeping teachers' skills up to date (Meroni, Vera-Toscano \& Costa, 2015). In addition to teacher skills and content knowledge, good teachers have an additional sat of values that are key to student achievement such as the ability to connect to students and their expectations for students (Baumert et al., 2010; Meroni, VeraToscano \& Costa, 2015). Furthermore, students perform better when they have a positive view towards their teachers (Weiss \& Garcia, 2015). To that end, countries such as Kosovo ought to target teachers' characteristics if they intend to improve student achievement.

Kosovo participated for the first time in the 2015 PISA assessments, the current article made use of the PISA data explorer provided by OECD. The country welcomed the assessment tests since they were considered as a possibility to receive feedback on the education quality. Although, the results were disappointing, PISA provided an unbiased feedback along with information on factors which influence student achievement, including teacher characteristics and school resources. The information about teacher characteristics can be used both, as a factor that explains current low performance and provides information on where to improve. In view of existing research, this paper will examine the data provided about teacher quality in Kosovo, describe weak domains and provide a platform for future interventions with a special focus on improving the quality of teaching while also adding to existing literature which is still lacking (Meroni, Costa \& Vera-Toscano, 2015).

\section{The performance of Kosovar students in PISA}

According to PISA results Kosovo ranks among the three worst performing countries. The country averages $(362,378,347)$ are well below the OECD average $(490,493$, 493). Kosovo is also much worse than other countries in the region such as Albania and Macedonia. In mathematics, Kosovar students scored 9 points lower than their peers in Macedonia and 51 points lower than students in Albania. In science Kosovar students scored 6 points less than students in Macedonia, and 39 points less than their peers in Albania. The situation is not any better in reading either, with Kosovar students scoring on average 5 points less than students in Macedonia and 58 points less than students in Albania. Similarly, in comparison to OECD average, Kosovar students score 128 points less in mathematics, 115 points less in science and finally 146 points less in reading. Not only is the student achievement in Kosovo the lowest in the region, but it is also incredibly far from the achievement in Western countries (please see table 1 below). The results of the first PISA test held in Kosovo revealed that there are gender differences in scores. Female students scored higher than male students in science and reading but in the meantime scored lower than male students in mathematics. While in differences in scores in science and math was only 9 points, the difference between genders in the reading test was relatively high as female students scored 36 points higher than male students (please see table 1 below).

PISA results for Kosovo support the current understanding in science that the place of residence Impacts academic performance with studies reporting that students in urban areas perform much higher compared to students living in rural settings. For instance, 
the results provide that the lowest performing students in math, reading, and science are students who live in villages. There is a continuous increase in scores from villages to cities, with students living in major cities performing best. It is rather unfortunate that the difference in scores between villages and towns is rather high. More specifically, students living in cities perform 39 points higher in math and science than students residing in villages. Similarly, the latter perform 50 points lower than their peers living in cities (please see table 1 below). An additional variable influencing student performance in Kosovo is the type of school that the students attend. The PISA data reveal that students attending private schools perform significantly higher than students who attend public education institutions. Students enrolled in private schools performed 66 points better in mathematics, 52 points higher in reading and 48 points higher in science compared to their peers attending public institutions (please see table 1 below).

Table 1

PISA scores according to gender, school type, residence and country.

\begin{tabular}{|c|c|c|c|c|}
\hline & & Mathematics & Reading & Science \\
\hline \multirow{4}{*}{ Residence } & Village & 339 & 320 & 356 \\
\hline & Small Town & 350 & 333 & 367 \\
\hline & Town & 363 & 348 & 380 \\
\hline & City & 378 & 370 & 395 \\
\hline \multirow{2}{*}{ School type } & Private & 426 & 398 & 425 \\
\hline & Public & 360 & 346 & 377 \\
\hline \multirow{2}{*}{ Gender } & Male & 366 & 329 & 374 \\
\hline & Female & 357 & 365 & 383 \\
\hline \multirow{7}{*}{ Region } & Albania & 413 & 405 & 427 \\
\hline & Macedonia & 371 & 352 & 384 \\
\hline & Slovenia & 510 & 505 & 513 \\
\hline & Kosovo & 362 & 347 & 378 \\
\hline & Germany & 506 & 509 & 509 \\
\hline & Finland & 511 & 526 & 531 \\
\hline & OECD Average & 490 & 493 & 493 \\
\hline
\end{tabular}

\section{Teacher characteristics in Kosovo}

Based on the data provided by PISA assessments, present research explores the following four sets of variables defining teachers' quality: teacher availability, training and collaboration; classroom management; teacher responsibility and tendencies; and teaching style/pedagogical techniques.

\section{Teacher Availability, Training, And Collaboration}

In terms of teaching staff, the table below provides a number of unexpected results. A shortage of teaching staff results in increased performance among students. It is interesting to discover that when there is a significant shortage in teaching staff, students perform better in mathematics (376), science (395) and reading (367) compared to the cases when there is no shortage of teaching staff in which case students performed worse in mathematics (364), science (379), and reading (347). In addition students who had 
inadequate teachers performed worse in mathematics (347), science (366) and reading (337) compared to students who had adequate teachers and therefore performed better in math (367), science (383) and reading (353).After the conduction of a significance test, the results suggest that there is a significant difference in student achievement $(p=0.00)$ between a considerable shortage in teaching staff and a little shortage of staff, with students performing 22 points higher in mathematics when there was a shortage in the staff. The same is evident in the reading achievement where students achieved 20 points higher when there was a considerable shortage of staff, and 27 points higher when there was a little shortage in the teaching staff, both differences were significant $(p=0.00)$. Similarly, students perform 16 points higher in science when there is a considerable shortage of staff, and 23 points higher when there is shortage compared when there is very little shortage, both differences are significant $(\mathrm{p}=0.00)$.

In terms of developments in school, PISA results provide that students performed worse when teachers are involved in development activities that happen more than one a week, which is also the case for the variables of educational goals discussing problems and joint problem solving. For instance, students perform best in mathematics (368), science (388) and reading (353) when teachers were engaged in development activities 3-4 times per year. Students perform worse when teachers participated in development activities more than once a week (348, 366 and 332 respectively). Similarly, setting educational goals more than once a week resulted in students performing worse in mathematics, science and reading $(350,373$ and 343$)$. Students perform best when educational goals were sat 3-4 times per week (378, 394 and 362). In addition, the data indicate the students perform best in math (385), science (393) and reading (363) when problems are discuses once a month. Finally, it was unexpected to discover that students perform best when teachers engaged in joint problem solving 1-2 times per year, with a score of 381 in math, 393 in science and 374 in reading.

The data reveals that teachers who attended in-service workshops designed for specific teachers, their students performed better in math (368), science (382) and reading (352) compared to students whose teachers did not participate in such trainings (357, 376 and 344 respectively). This was not the case with in-service workshops for specific issues because students whose teachers did not participate in such trainings received identical scores in science (378) and better scores in reading (347), compared to students whose teachers attended the respective trainings who had an advantage only in math (363). Finally, regardless of teachers participating in in-service training, students performed equally in science (381), but students whose teachers attended the training performed slightly better in math (363) and reading (349) compared to other students who did a little worse in math (360) and reading (347). Finally, these differences were not significant.

All things considered, results provided by PISA are unexpected and do not follow any trends and are challenging to interpret. The data indicate that students perform best when there is shortage of teaching staff, when teachers become involved in development activities, as well as when setting educational goals, joint problem solving and problem discussion are fostered once or twice a year as opposed to becoming involved in such 
activities more often. Furthermore, the data also provide that participation in different training programs had little to no impacts, of these programs the one that had most significant impact was the in-service workshops for specific teachers. Regardless, this data is chaotic in nature and contrary to literature. While it is expected that a shortage in teaching staff, rare involvement in development activities and joint discussions would result in low performance, it is the opposite in Kosovo because it increases the achievement in students. One way to explain this is by arguing that teacher quality is low in Kosovo and students attend private lessons in order to account for teachers that are missing or for other shortcomings of teachers.

\section{Teaching Style/Pedagogical Techniques}

The data which focus one teachers' performance and teaching styles reviled that students performed best in mathematics when teachers demonstrated ideas every lesson (376), shared performance status in most lessons (381), provided feedback on strengths most lessons (378), provided feedback on how to improve (377) and how to reach learning goals in most lessons (370). Additionally, students performed best in mathematics when teachers showed interest in every student in most lessons (385), teachers give extra help in most lessons (375), teachers helped in some lessons (383), teachers express opinions in most lessons (378), teachers explained scientific ideas (384), discussed with students (382), and discussed students' questions (380) in most lessons. Students performed best in science when teachers demonstrated ideas every lesson (394), shared performance status in most lessons (398), provided feedback on strengths most lessons (397), provided feedback on how to improve (389) and how to reach learning goals in most lessons (392).

Table 2

PISA scores according to teacher characteristics.

\begin{tabular}{lllllllllll}
\hline & \multicolumn{1}{l}{$\begin{array}{l}\text { Teacher interested in every } \\
\text { student }\end{array}$} & \multicolumn{1}{c}{ Teacher gives extra help } & \multicolumn{2}{c}{ Teacher helps } \\
\hline & Math & Science & Reading & Math & Science & Reading & Math & Science & Reading \\
\hline Every lesson & 363 & 381 & 351 & 360 & 377 & 348 & 359 & 375 & 346 \\
\hline Most Lessons & 385 & 401 & 368 & 375 & 387 & 354 & 382 & 399 & 364 \\
\hline Some Lessons & 367 & 379 & 350 & 365 & 388 & 353 & 383 & 402 & 371 \\
\hline Never/hardly ever & 323 & 341 & 308 & 368 & 371 & 334 & 364 & 374 & 326 \\
\hline
\end{tabular}

Additionally, students performed best in science when teachers showed interest in every student in most lessons (401), teachers gave extra help in some lessons (388), teachers helped in some lessons (402), teachers express opinions in most lessons (392), teachers explained scientific ideas in every lesson (398), teachers discussed with students in most lessons (395), and teachers discussed students' questions (397) in every lesson. Students performed best in reading when teachers demonstrated ideas every lesson (361), shared performance status in most lessons (369), provided feedback on strengths most lessons (369), provided feedback on how to improve (363) and how to reach learning goals in most lessons (364). Additionally, students performed best in reading when teachers showed interest in every student in most lessons (368), teachers give extra 
help in most lessons (354), teachers helped in some lessons (371), teachers express opinions in most lessons (356), teachers explained scientific ideas in most lessons (370), discussed with students (367), and discussed students' questions (369) in every lesson.
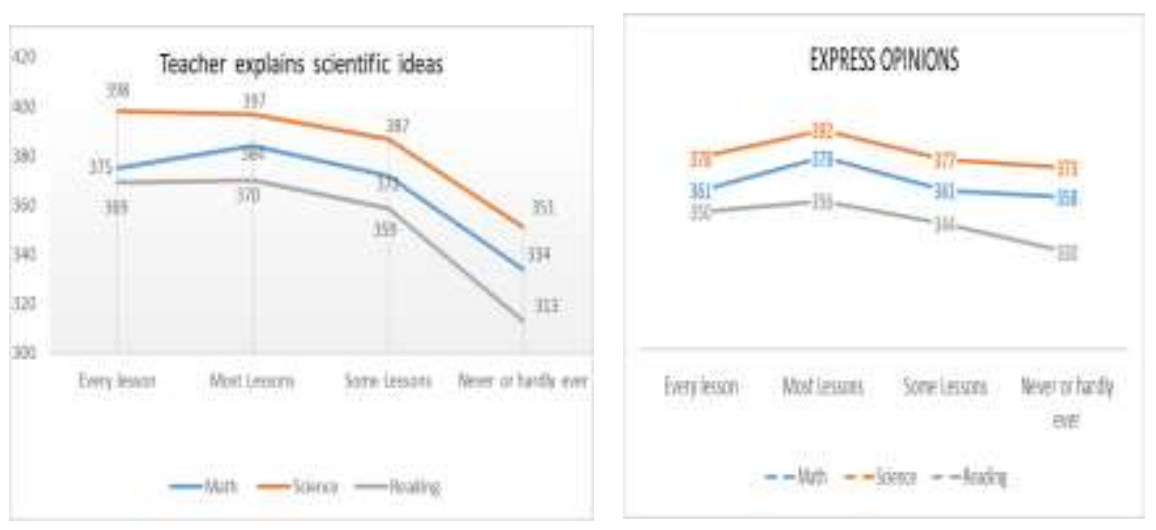

Figure 1

PISA scores according to teacher characteristics.

To summarize, students performed 40 points lower when teachers never or hardly ever were interested in them $(\mathrm{p}=0.00)$, similarly students performed 63 points higher in mathematics when teachers were mostly interested in them compared to students whose teachers were never or hardly ever interested in them $(\mathrm{p}=0.00)$.In reading the data suggest that the interest of teacher interest is crucial to achievement. To that end, students whose teachers where interested in them in every lesson performed 42 points higher compared to students who were never the object of teacher interest $(\mathrm{p}=0.00)$. Similarly, students who were the object of teacher interest in most lessons and some lessens perform 60 and 42 points higher compared to students who never received teacher interest $(\mathrm{p}=0.00)$. In conclusion, since all differences were significant, any degree of teacher interest leads to higher levels of achievement in reading. Similarly, students performed lowest in science when the teachers were not interested in them. Specifically, students performed 40 points higher when teachers were interested in them every lesson, 61 points higher when teacher were interested in most lessons, and 39 points higher when teachers were interested in some lessons, compared to students who were never or hardly ever the object of teacher interest. Since these differences in achievement were significant $(\mathrm{p}=0.00)$, the data suggest that teacher's interest in every students is a powerful indicator of student achievement in science. 


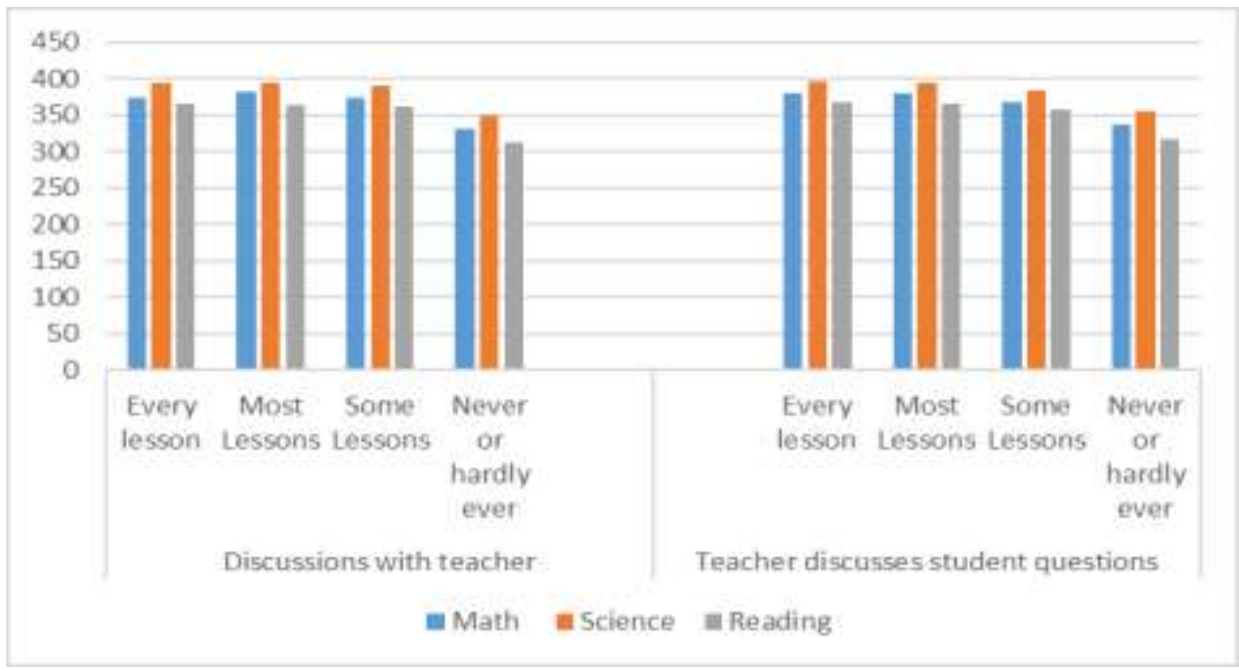

Figure 2

PISA scores according to teacher characteristics.

When it comes to teachers giving extra help the data are inclusive. To that end, students in classes offered extra help during all lessons, performed 16 points lower in mathematics compared to students who received help in most lessons, difference that was significant $(\mathrm{p}=0.00)$. The same trend is evident in terms of achievement in science. More specifically, students achieve 10 points more when teachers provided help during most sessions, and 11 points more when teachers provided help during some lessons compared to students who received help from the teachers in every session. These differences were significant ( $\mathrm{p}=0.00$ and $\mathrm{p}=0.04$ respectively).

According to PISA 2015 data, students who received help from teachers in most sessions and in some sessions outperformed students who received help in every session, by 23 and 24 points respectively $(\mathrm{p}=0.00)$. Similarly, students who received help in most and some sessions outperformed students who received help in every session by 18 and 25 points in reading $(\mathrm{p}=0.00)$. The achievement trends remained the same for science when students who received help in most/some sessions outperformed the students who received help in every lesson by 25 and 28 points respectively $(\mathrm{p}=0.00)$.

The PISA 2015 data suggest that students who express their opinions in most lessons outperform students who express their opinions every lessons by 17 points as well as the students who express opinions in some lessons by the same number of points, namely 17 in mathematics $(\mathrm{p}=0.00$ and $\mathrm{p}=0.03$ ). No significant differences were evident between groups in the reading achievement. Finally, students who expressed their opinion in most lessons outperformed students who expressed their opinions every lesson by 14 points $(\mathrm{p}=0.00)$ and students who expressed opinion in some lessons by 15 points $(\mathrm{p}=0.01)$. 
According to the PISA 2015 data students who never or almost never benefited from teachers explaining ideas performed 38 points lower than students who benefit from this approach during some lessons, 50 points lower than students who had teachers explain ideas during most lessons, and finally 44 points lower compared to students who benefited from teachers explaining ideas every lesson $(\mathrm{p}=0.00)$. The same trend is noticeable in the performance in the reading scale with students who never or almost never benefit from teachers explaining ideas being outperformed by students who have teachers that explain ideas during some lessons (46 points, $\mathrm{p}=0.00)$, most sessions $(57$ points, $\mathrm{p}=0.00$ ) and in every session or almost every session ( 56 points, $\mathrm{p}=0.00$ ). Finally, students who never or almost never benefited from teachers explaining ideas performed 36 points lower in science compared to students who had teachers that explained ideas during some lessons, and 45 points lower than students who had teachers explain ideas in most lessons, and finally 47 points lower compared to students who benefited from teachers who explained ideas in almost every lesson/every lesson $(\mathrm{p}=0.00)$.

Table 3

PISA scores according to teacher characteristics.

\begin{tabular}{lllll}
\hline \multirow{2}{*}{ Teacher demonstrates an idea } & & Math & Science & Reading \\
& Every lesson & 376 & 394 & 361 \\
& Most Lessons & 374 & 389 & 361 \\
& Some Lessons & 371 & 387 & 358 \\
& Never/hardly ever & 342 & 359 & 325 \\
\hline \multirow{2}{*}{ Teacher shares performance status } & Every lesson & 357 & 370 & 336 \\
& Most Lessons & 381 & 398 & 369 \\
& Some Lessons & 378 & 394 & 365 \\
& Never/hardly ever & 338 & 357 & 322 \\
\hline \multirow{2}{*}{ Feedback on strength } & Every lesson & 361 & 377 & 340 \\
& Most Lessons & 380 & 397 & 369 \\
& Some Lessons & 371 & 387 & 360 \\
& Never/hardly ever & 340 & 356 & 318 \\
\hline
\end{tabular}

Students who discussed with teachers in almost every lesson/every lesson performed 43 points higher in mathematics, students who discussed with teachers during most sessions performed 50 higher, and students who discussed with teachers in some lessons performed 43 points higher compared to students who almost never/never discussed with teachers $(\mathrm{p}=0.00)$. Students who never or almost never discussed with teachers performed 49 points lower than students who discussed with teachers in some lessons, 53 points lower than students who discussed with teachers in most lessons, and finally 54 points lower compared to students who almost every lesson/every lesson discussed with teachers $(\mathrm{p}=0.00)$. Finally, students who never or almost never discussed with teachers were outperformed by students who discussed with teachers in some lessons by 
40 pints, by students who discussed with teachers in most lessons by 45 points, and by students who discussed with teachers in every lesson by 44 points in science $(p=0.00)$.

Students who never or almost never benefited from discussing their questions with teachers were outperformed from students who did so in some lessons by 32 points, in most lessons by 43 points and finally by students who did so in almost every session/every session by 43 points in mathematics $(\mathrm{p}=0.00)$. The same trend is evident in the achievement scores in reading as well. Specifically, students who never or almost never benefited from discussing their questions with teachers were outperformed from students who did so in some lessons by 41 points, in most lessons by 49 points and finally by students who did so in almost every session/every session by 51 points in reading $(p=0.00)$. Finally, similar to finds on student achievement in mathematics and reading, in science, students who never or almost never benefited from discussing their questions with teachers were outperformed from students who did so in some lessons by 29 points, in most lessons by 41 points and finally by students who did so in almost every session/every session by 42 points $(\mathrm{p}=0.00)$.

Students who never or almost never benefited from teachers demonstrating an idea were outperformed from students whose teachers did so in some lessons by 28 points, in most lessons by 31 points and finally by students whose teachers did so in almost every session/every session by 34 points in mathematics $(\mathrm{p}=0.00)$. Students who never or almost never benefited from teachers demonstrating an idea were outperformed from students whose teachers did so in some lessons by 33 points, in most lessons by 36 points and finally by students whose teachers did so in almost every session/every session by 36 points in reading $(\mathrm{p}=0.00)$. Students who never or almost never benefited from teachers demonstrating an idea were outperformed from students whose teachers did so in some lessons by 27 points, in most lessons by 29 points and finally by students whose teachers did so in almost every session/every session by 35 points in science $(\mathrm{p}=0.00)$.

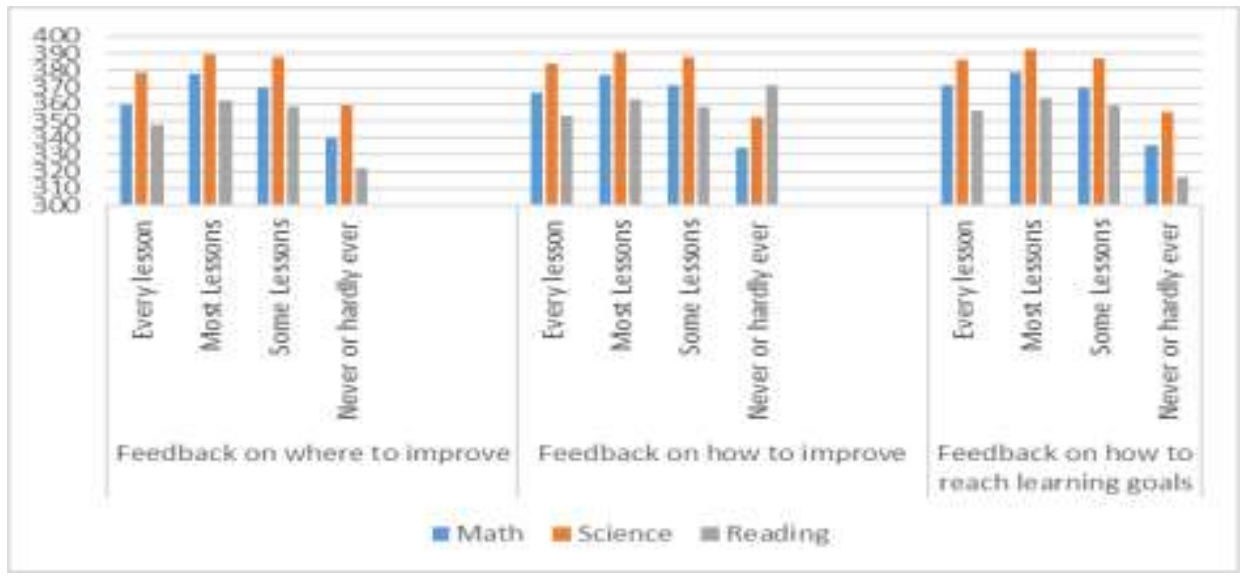

Figure 3

PISA scores according to teacher characteristics. 
Students who had teachers who shared the performance status in every lesson/every lesson performed 19 points higher in mathematics, students who benefited from such performance status shares in most sessions performed 43 higher, and students who did so in some lessons performed 38 points higher compared to students who almost never/never received performance statuses from teachers $(\mathrm{p}=0.00)$. Students who never or almost never had teachers share the performance status of students performed 47 points lower than students who received performance statuses during some lessons, 53 points lower than students who did so in most lessons, and finally 13 points lower compared to students who almost every lesson/every lesson received performance statuses $(\mathrm{p}=0.00)$. Finally, students who never or almost never received performances statuses were outperformed by students who received performance statuses in some lessons by 37 pints, by students who received performance information in most lessons by 41 points, and by students who received performance information in every lesson by 13 points in science $(\mathrm{p}=0.00)$.

According to the PISA 2015 data students who never or almost never benefited from feedback on strengths performed 31 points lower than students who benefit from this approach during some lessons, 40 points lower than students who received feedback on strengths during most lessons, and finally 21 points lower compared to students who received feedback on strengths after every lesson in mathematics $(p=0.00)$. The same trend is noticeable in the performance in the reading scale with students who never or almost never benefit from teachers providing feedback on strengths being outperformed on reading achievement by students who receive such feedback during some lessons (42 points, $\mathrm{p}=0.00$ ), most sessions ( 51 points, $\mathrm{p}=0.00$ ) and in every session or almost every session ( 22 points, $\mathrm{p}=0.00$ ). Finally, students who never or almost never benefited from feedback on strengths performed 31 points lower in science compared to students who received such feedback during some lessons, and 40 points lower than students who received such feedback in most lessons, and finally 20 points lower compared to students who benefited from teachers' feedback on strengths in almost every lesson/every lesson $(\mathrm{p}=0.00)$.

Students who had teachers who provided information on where to improve in every lesson/every lesson performed 20 points higher in mathematics, students who benefited from such information in most sessions performed 38 points higher, and students who received such feedback in some lessons performed 30 points higher compared to students who almost never/never received information on where to improve $(p=0.00)$. Students who never or almost never received feedback on where to improve performed 36 points lower than students who received information on where to improve during some lessons, 40 points lower than students who received such feedback in most lessons, and finally 26 points lower compared to students who almost every lesson/every lesson received feedback on where to improve $(p=0.00)$. Finally, students who never or almost never received information on where to improve were outperformed by students who received such information in some lessons and in most lessons by 30 points, and by students who received such information in every lesson by 20 points in science $(\mathrm{p}=0.00)$. 
According to the PISA 2015 data students who never or almost never benefited from feedback on how to improve performed 37 points lower than students who benefit from this approach during some lessons, 42 points lower than students who received feedback during most lessons, and finally 32 points lower compared to students who received feedback on how to improve after every lesson in mathematics $(\mathrm{p}=0.00)$. The same trend is noticeable in the performance in the reading scale with students who never or almost never benefit from teachers providing feedback on how to improve being outperformed on reading achievement by students who receive such feedback during some lessons (42 points, $\mathrm{p}=0.00$ ), most sessions ( 46 points, $\mathrm{p}=0.00$ ) and in every session or almost every session (37 points, $\mathrm{p}=0.00$ ). Finally, students who never or almost never benefited from feedback on how to improve performed 36 points lower in science compared to students who received such feedback during some lessons, and 39 points lower than students who received such feedback in most lessons, and finally 32 points lower compared to students who benefited from feedback on how to improve in almost every lesson/every lesson $(\mathrm{p}=0.00)$.

According to the PISA 2015 data students who never or almost never benefited from feedback on how to reach learning goals performed 34 points lower than students who benefit from this approach during some lessons, 43 points lower than students who received feedback on how to reach learning goals, and finally 35 points lower compared to students who received such feedback after every lesson in mathematics $(\mathrm{p}=0.00)$. The same trend is noticeable in the performance in the reading scale with students who never or almost never benefited from feedback on how to reach learning goals being outperformed on reading achievement by students who receive such feedback during some lessons ( 42 points, $\mathrm{p}=0.00$ ), most sessions ( 46 points, $\mathrm{p}=0.00$ ) and in every session or almost every session ( 39 points, $\mathrm{p}=0.00$ ). Finally, students who never or almost never benefited from feedback on how to reach learning goals performed 32 points lower in science compared to students who received such feedback during some lessons, and 37 points lower than students who received such feedback in most lessons, and finally 32 points lower compared to students who benefited from feedback in almost every lesson/every lesson $(\mathrm{p}=0.00)$.

The data on teachers' techniques and practices are again unexpected and contrary to literature. Experts agree that the application of techniques which foster learning in students in every lesson (such as teacher interested in every student, teacher gives extra helps, teacher helps, express opinion, teacher explains scientific ideas, discussions with teacher, teachers shares performance status, teachers provides feedback on where to improve, on strengths, on how to improve and on how to reach learning goals) would result in these student performing best. Nevertheless, in Kosovo the application of such techniques does not result in the highest achievements since these students performed worse across all domains compared to students who were exposed to such techniques in most lessons or some lessons. This result is contrary to what is expected and proves the need for additional research to explore the developments in classrooms across Kosovo. 


\section{DISCUSSION}

The results of the current paper provide that teacher characteristic do play a role in student performance and achievement. Although the trends in the case of Kosovar students admittedly were chaotic to a degree, they still show that teachers' views and practices do play a detrimental role in student learning and achievement. The topic of student performance becomes even more sensitive when studies maintain that student performance is among the strongest predictors of income in the future (Hanushek 2011; Hanushek and Woessman 2009; Hanushek and Zhang 2009; Lazear 2003; Mulligan 1999), in reality teacher quality is the key variable determining student achievement (Darling-Hammond 2000) since teacher quality (Ferguson 1991) and teacher characteristics (Ferguson 1991; Sanders and Rivers 1996; Jordan et al. 1997; DarlingHammond 1997, 1999, 2000) determine student learning (Darling-Hammond 2000). Interestingly enough, literature suggests that teacher quality is so important that students who spent one year with a teacher that is not effective never recover while students who spent a year with an effective teacher have benefits up to two years after this experience (Seebruck, 2015).The study of Meroni and colleagues (2015) which explored the impact of teacher skills in student achievement as measured by PISA, discovered that once teacher skills are added to the model they explained $14 \%$ of the variance in mathematics scores and $17 \%$ of the variance in reading scores. The finding of this research raised the question of variances in teachers' quality across countries participating in PISA assessments as well as the impact of teachers' quality student performance. The authors further argue that these results do not indicate that teachers are to blame for the student performance. To that end, low performing countries may not consider teaching as a prestigious profession thus the government may not be doing enough to attract skilled individuals to the teaching profession (Meroni, Vera-Toscano \& Costa, 2015).

Similarly, Hanushek \& Woessman (2011) indicated that differences in students' performance across countries can be explained by differences in school systems and school characteristics. In order to improve students' skills policy builders should improve learning environments (Meroni, Vera-Toscano \& Costa, 2015). While it is clear that good teachers are important for student learning, it is not so clear what are the characteristics of good teachers. A number of studies have reported that teachers' education and experience are two variables that influence student achievement, but a number of other researchers argue that these two variables although easy to measure are the once that are weakly linked to student achievement (Goldhaber and Brewer, 2000).It was interesting to discover that teachers who have content knowledge are not better than teachers who have pedagogical knowledge (Baumert et al., 2010). While people generally think that knowledge of the subject is what matters, studies discovered that teacher who had strong pedagogical knowledge where crucial, since students who had these teachers had a full year more learning than did students whose teachers had content knowledge but had weak pedagogical skills (Baumert et al., 2010). Considering the findings of the current analysis as well as existing literature, the impact of teacher characteristics needs to not be neglected in the policy making in Kosove. Rather, it should be in the centre of the education debate. A focus on school-based variables 
provides valuable information in relation to policy development as well as school management (Agasist \& Longobardi, 2016).

The focus on school-level variables paves the way for more complete and useful implications from the perspective of both policies and management aspects

\section{CONCLUSION}

Teachers are important to learning and performance, but it still remains unclear what a good teacher possesses. Generally, qualities such as education and experience have been considered as attributes of a good teacher but these have also been the indicators that have not been linked to student achievement (Meroni, Costa \& Vera-Toscano, 2015). As such the debate has shifted to teacher characteristic such as teaching practices, attributes, approaches and views towards teaching.

There is compelling evidence which supporting the understanding that teacher characteristics determine student achievement. For instance, a longitudinal study on the link between teacher quality and student performance conducted in Texas reported that fourth grade students who had effective teachers for three years performed 35 points higher in reading tests and 50 points higher in mathematics compared to students who were taught by weak teachers (Jordan et al., 1997). This finding is in line with the arguments of Hanushek (1992) who explains that the impacts of being taught even a single academic year by an ineffective teacher can never be overcome, as well as with the declaration of Prince (2002) that teacher quality is the most important variable determining student performance. In light of this evidence countries such as Kosovo which are at the bottom of PISA assessments may find investments in improving teacher characteristics valuable.

This paper argues that the governmental structures in Kosovo need to undertake a number of initiatives in order to improve student achievement in the country. Initially, interventions that target gender, residence and school differences need to be undertaken. Of equal importance in this road ahead are interventions which target teach characteristics which includes but is not limited to content knowledge and pedagogical techniques. This paper maintains that the data about teacher characteristics and practices in Kosovo is confusing, often incomprehensive and inconclusive but it does document that we know little of how we are teaching students in Kosovo. Prior to any recommendations being employed, governments structures need to launch a full scale research program which would aim to gather as much data as possible on what teachers are applying in classrooms, what their level of content knowledge is and finally what types of teaching techniques they are employing. The data from this research would be invaluable in deciphering PISA results as well as be the foundation ground for the development of policy and intervention. Once we obtain a better understanding of the current situation, Kosovo ought to evaluate what other countries have done prior to drafting an intervention program. To that end, the improvement of teacher characteristics should be the core of interventions, even more so than technology and school resources. 
Currently, Kosovo is still processing the PISA feedback to its education system. To that end soon there will be the shift to the question of how to respond and mitigate the situation. In the case of Kosovo policy builders should focus on 4 immediate issues pertaining to gender, residence type, and school type. First, more should be done to close the gender gap in reading scores. Boys scored significantly lower than girls and experts should discover reasons behind such performance. Secondly, PISA results documented that the lowest performing students resided in villages. Consequently, leadership structures need to take immediate action to improve the teaching situation in schools located in villages and other remote areas either in terms of additional funding, teacher training programs or student transportation to major schools. Another issue that demands consideration is the fact that private schools are teaching students much better than public schools. Evidently, there is a need to understand what teaching practices differ and what public schools are lacking.

On the topic of improving teacher quality and teacher characteristics there are five excellent practices that have yielded highly positive results for a number of countries, and could do the same for Kosovo. First, Kosovo should employ teacher assessment. Teachers prior to applying for a job position should take an examination-Teachers' Qualification Examination- a test that assesses their content knowledge as well as teaching skills, and professional ethics. The teaching profession is not a lifetime job position and teachers should be expected to renew their licenses every 5 years. License renewal does not only entail a test but in addition teachers need to prove that they have gathered 200 hours of training during the five years for which they had the license in order to be able to take part in the exam (OECD, 2016a). All things considered, offering access to certified teachers should be the aim of any country that wants to impact education quality (Seebruck, 2015). Finally, the Kosovar government needs to understand that financial investments are not the answer, nor will they bring an end to problems because schools that have the highest investments are the ones who have low levels of student achievements (Seebruck, 2015). This is a compelling argument because government structures in Kosovo exhibit a tendency to blame the lack of financial resources for all shortcomings. Provided that financial resources are not the key factor, leadership structures can focus on doable and reasonable initiatives.

Another practice that has helped China improved its performance is the salary system for teachers who receive a basic salary plus bonuses depending on the performance (OECD, 2016a). The data on student performance in PISA tests provide that in countries where teacher pay is a subject to performance, students score one-quarter of a standard deviation better in math and reading as well as $15 \%$ higher in science compared to students that come from countries where teacher salaries are not adjusted for performance. Importantly, this study suggests that countries who adjust teachers' salaries according to performance are the ones that have the highest performing students, and students in these regions by the age of 15 will have learned one year more in math and reading and half a year in science (Woessmann, 2011). Based on existing evidence, adjusting teacher salaries to performance is a compelling argument for countries such as Kosovo where teacher performance is never evaluated or taken seriously for that matter. 
Kosovo should employ other successful practices including offering elective classes for students, promoting creativity and critical thinking, and helping students become active participants in their education by providing them with freedom and help to focus on their research interests. An additional possibility to increase education quality is to focus on teachers' development needs. For instance, Estonia managed to increase its performance by providing teachers with counselling centres which offered resources to help teachers increase their teaching quality. In the meantime, these centers offered professional development programs for teachers (OECD, 2016b). Moreover, one problem that Kosovo has and is similar to other countries is the fact that the teaching profession is not an attractive profession. The low social status of this profession fails to attract high quality candidates. One possibility that other countries have used to increase the status of teaching professions has been to increase salaries and develop centres in Universities to enhance professional development of teachers as well as to research teaching skills. Cooperation between education providers is also a prerequisite to success. As such, the Ministry of education in Singapore reduced the curriculum in order to provide space for activities that emphasized inquiry-based learning. Teachers have also been provided with time to discuss which each other about planning lessons and learning activities. Furthermore, schools have been provided with autonomy to decide on their innovative programs, which has resulted in a culture of cooperation, continuous learning and improvement (OECD, 2016c); practices that eventually enhanced student achievement. Conclusively, Kosovo can learn much from countries which have improved their education systems by initiating specific policies. To that end, these policies present a foundation stone based on which Kosovo can build a strong education system.

\section{REFERENCES}

Agasisti, Tommaso \& Longobardi, Sergio. (2017). Equality of Educational Opportunities, Schools' Characteristics and Resilient Students: An Empirical Study of EU-15 Countries Using OECD-PISA 2009 Data. Social Indicators Research. 134. 10.1007/s11205-016-1464-5.

Baumert, J., Kunter, M., Blum, W., Brunner, M., Voss, T., Jordan, A., et al. (2010). Teachers' mathematical knowledge, cognitive activation in the classroom, and student progress. American Educational Research Journal, 47(1), 133-180.

Carvalho, L. (2012) The Fabrications and Travels of a Knowledge-Policy Instrument, European Educational Research Journal, 11(2), 172-188. http://dx.doi.org/10.2304/eerj.2012.11.2.172

Cordero, J. M., \& Gil, M. (2018). The effect of teaching strategies on student achievement: An analysis using TALIS-PISA-link. Journal of Policy Modelling https://doi.org/10.1016/j.jpolmod.2018.04.003

Darling-Hammond, L. (2000). Teaching and Knowledge: Policy Issues Posed by Alternative Certification for Teachers. Peabody Journal of Education, 67(3):123-154. 
European Commission. (2004). Common European principles for teacher competences and qualifications.

Ferguson, Ronald F. (1991). Paying for Public Education: New Evidence on How and Why Money Matters. Harvard Journal of Legislation, 28, 465-498.

Goldhaber, D., \& Brewer, D. (2000). Does certification matter? High school teacher certification status and student achievement. Educational Evaluation and Policy Analysis, 22(2), 129-145.

Hanushek, E. A., \& Woessman, L. (2011). The economics of international differences in educational achievement.

Hanushek, E. A. (2011). The economic value of higher teacher quality. Economics of Education Review, 30(3), 466-479.

Hanushek, E. A., \& Woessman, L. (2011). The economics of international differences in educational achievement.

Hanushek, E. A. and Woessmann, L. (2009). Do Better Schools Lead to More Growth? Cognitive Skills, Economic Outcomes, and Causation. NBER Working Paper 14633. Cambridge, A: National Bureau of Economic Research.

Hanushek, E. A. and Zhang, L. (2009). Quality-Consistent Estimates of International Schooling and Skill Gradients. Journal of Human Capital, 3(2), 107-143.

Jordan, H. R., Mendro, R. L. and Weersinghe, D. (1997). Teacher Effects on Longitudinal Student Achievement: A Preliminary Report on Research on Teacher Effectiveness. Paper presented at the National Evaluation Institute, Indianapolis. Kalamazoo, MI: CREATE, Western Michigan University.

Lazear, Edward P. (2003). Teacher Incentives. Swedish Economic Policy Review, 10(3), 179-214.

Lawn, M. (2011) Standardizing the European Education Policy Space. European $\begin{array}{llll}\text { Educational Research } & \text { Journal, } & \text { 259-272. }\end{array}$ http://dx.doi.org/10.2304/eerj.2011.10.2.259

Mangez, E. \& Hilgers, M. (2012) The Field of Knowledge and the Policy Field in Education: PISA and theproduction of knowledge for policy, European Educational Research Journal, 11(2), 189-205. http://dx.doi.org/10.2304/eerj.2012.11.2.189

Meroni, E.C., Vera-Toscano, E., Costa, P. (2015). Can low skill teachers make good students? Empirical evidence from PIAAC and PISA. Journal of Policy Modelling, pp. 308-323.

Mulligan, Casey B. (1999). Galton versus the Human Capital Approach to Inheritance. Journal of Political Economy, 107(6),184-224.

OECD. (2005). Teachers matter: Attracting, developing and retaining effective teachers. Paris: OECD. 
Organisation for Economic Cooperation and Development (OECD) (2009a) PISA 2009 Results: what students know and can do. Student Performance in Reading, Mathematics and Science. Paris: OECD.

OECD. (2016a). PISA High Performers: China. Retrieved December 12, 2016, from OECD: http://www.oecd.org/pisa/PISA-2015-china.pdf.

OECD. (2016b). PISA High Performers: Estonia. Retrieved December 12, 2016, from OECD: http://www.oecd.org/pisa/PISA-2015-estonia.pdf

OECD. (2016c). PISA High Performers: Singapore. Retrieved December 12, 2016, from OECD: http://www.oecd.org/pisa/PISA-2015-singapore.pdf

Ozga, J. (2012) Assessing PISA, European Educational Research Journal, 11(2), 166171. http://dx.doi.org/10.2304/eerj.2012.11.2.166.

Pereyra, M.A., Kottohof, H.-G. \& Cowen, R. (Eds) (2011) An Introduction to the Comparative Puzzle, inM.A. Pereyra, H.-G. Kottohof \& R. Cowen (Eds) PISA Under Examination: changing knowledge, changing tests, and changing Schools. Rotterdam: Sense

Prince, C. D. (2002). The Challenge of Attracting Good Teachers and Principals to Struggling Schools. American Association of School Administrators.

Sanders, W. L. and Rivers, R. J. (1996). Cumulative and Residual Effects of Teachers on Future Student Academic Achievement. Knoxville, TN: University of Tennessee Value-Added Research and Assessment Center. Accessed on 19 March 2014 http://bulldogcia.com/Documents/Bulldog_CIA/Articles/sanders_rivers.pdf\&gt;

Seebruck R. (2015). Teacher quality and student achievement: A multilevel analysis of teacher credentialization and student test scores in California High Schools. McGill Sociological Review, 5, 1-18.

Schleicher, A. (2013) Use Data to Build Better Schools'. TEDTalks, February 21.https://www.youtube.com/watch?v=7Xmr87nsl74

Weiss, C. C., \& Garcia, E. (2015). Student engagement and academic performance in Mexico: Evidence and Puzzles from PISA. Comparative Education Review, 59(2), 305331.

Woessman, L. (2011, Spring). Education Next. Retrieved December 23, 2016, from Education Next: http://educationnext.org/files/ednext_20112_Woe 